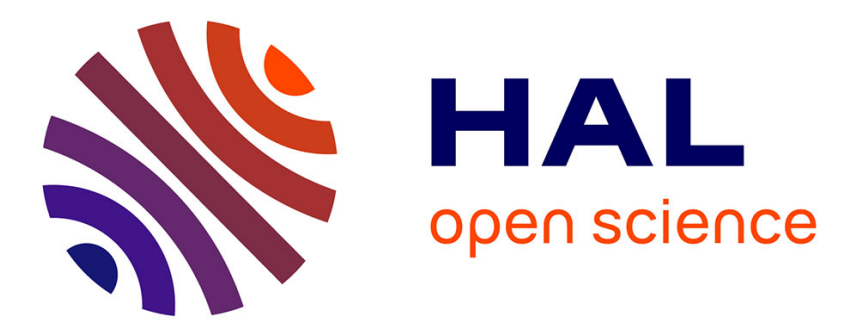

\title{
Cotrimoxazole as a treatment for recurrent idiopathic anterior scleritis: A single-center experience in 20 patients
}

Philip Bielefeld, Aurore Muselier, Hervé Devilliers, Catherine Creuzot Garcher, Géraldine Muller, Jean-François Besancenot, Alain Bron

\section{To cite this version:}

Philip Bielefeld, Aurore Muselier, Hervé Devilliers, Catherine Creuzot Garcher, Géraldine Muller, et al.. Cotrimoxazole as a treatment for recurrent idiopathic anterior scleritis: A single-center experience in 20 patients. Ocular Immunology and Inflammation, 2015, 23 (2), pp.184-187. 10.3109/09273948.2013.874446 . hal-01353278

\section{HAL Id: hal-01353278 \\ https://hal.science/hal-01353278}

Submitted on 27 May 2020

HAL is a multi-disciplinary open access archive for the deposit and dissemination of scientific research documents, whether they are published or not. The documents may come from teaching and research institutions in France or abroad, or from public or private research centers.
L'archive ouverte pluridisciplinaire HAL, est destinée au dépôt et à la diffusion de documents scientifiques de niveau recherche, publiés ou non, émanant des établissements d'enseignement et de recherche français ou étrangers, des laboratoires publics ou privés. 


\title{
Cotrimoxazole as a Treatment for Recurrent Idiopathic Anterior Scleritis: A Single-center Experience in 20 Patients
}

\author{
Philip Bielefeld MD, Aurore Muselier MD, Hervé Devilliers MD, Catherine \\ Creuzot-Garcher MD, PHD, Géraldine Muller MD, Jean-François Besancenot \\ MD, PHD \& Alain M. Bron MD, PHD
}

To cite this article: Philip Bielefeld MD, Aurore Muselier MD, Hervé Devilliers MD, Catherine Creuzot-Garcher MD, PHD, Géraldine Muller MD, Jean-François Besancenot MD, PHD \& Alain M. Bron MD, PHD (2015) Cotrimoxazole as a Treatment for Recurrent Idiopathic Anterior Scleritis: A Single-center Experience in 20 Patients, Ocular Immunology and Inflammation, 23:2, 184-187

To link to this article: http://dx.doi.org/10.3109/09273948.2013.874446

Published online: 16 Jan 2014.

Submit your article to this journal

Џll Article views: 99

Q View related articles $₫$

View Crossmark data

Citing articles: 1 View citing articles 


\title{
Cotrimoxazole as a Treatment for Recurrent Idiopathic Anterior Scleritis: A Single-center Experience in 20 Patients
}

\author{
Philip Bielefeld, $\mathrm{MD}^{1}$, Aurore Muselier, $\mathrm{MD}^{2}$, Hervé Devilliers, ${ }^{1}{ }^{1}$, \\ Catherine Creuzot-Garcher, $\mathrm{MD}, \mathrm{PHD}^{2}$, Géraldine Muller, $\mathrm{MD}^{1}$, \\ Jean-François Besancenot, MD, PHD $^{1}$, and Alain M. Bron, MD, HHD $^{2}$ \\ ${ }^{1}$ Department of Internal Medicine and Systemic Diseases and ${ }^{2}$ Department of Ophthalmology, University \\ Hospital, Dijon, France
}

Anterior scleritis presentations range from a benign course to severe cases such as scleral necrosis. About one-third of cases are associated with systemic diseases, mainly rheumatoid arthritis and granulomatosis with polyangiitis (GPA) ${ }^{1}$ Without treatment, anterior scleritis can be complicated with sightthreatening conditions, such as keratitis, uveitis, glaucoma, macular edema, exudative retinal detachment. and scleromalacia perforans. Anterior or posterior sclera may be involved by scleral wall inflammation. ${ }^{1,2}$

The mainstay of the initial treatment for scleritis is a nonsteroidal anti-inflammatory drug (NSAID). ${ }^{1,3}$ It was recently shown in a large series of patients with idiopathic diffuse or nodular scleritis with a low degree of scleral inflammation that NSAIDs were effective in about half of the cases. ${ }^{3}$ For more severe cases, steroidal anti-inflammatory therapy or immunosuppressive agents or biotherapies are usually indicated.

We report on 20 cases presenting with recurrent idiopathic anterior scleritis treated with cotrimoxazole (CTX), a corticosteroid-sparing agent by means of its immunomodulatory properties, as an alternative to NSAIDs. Our first case did not respond to NSAIDs. Therefore, we treated her with CTX, because of the presence of low titers of anti-proteinase 3 antibodies and following the recommendations for localized GPA treatment. The favorable outcome during several years in this patient prompted us to use CTX for patients with recurrent idiopathic anterior scleritis resistant to NSAIDs treatment (18 patients) or with contraindications to systemic NSAIDs (2 patients), as a trial before introducing long-lasting steroids or immunosuppressive treatment. All patients with anterior scleritis who received CTX between 2000 and 2012 were retrospectively identified through a medical chart database review. A complete examination was performed, including blood samples, in particular anti DNA, ANA, and ANA subtypes, anti$\mathrm{CCP}$, antineutrophil cytoplasmic antibodies, rheumatoid factor, VDRL TPHA, tuberculin skin test or interferon gamma release assay, and herpes virus simplex antibodies testing. Each patient benefited from chest x-ray or CT scan. We excluded patients with a known etiology of scleritis, including vasculitis, infectious diseases, or any other condition that may be associated with scleritis. Each patient received a daily combination of one tablet combining $800 \mathrm{mg}$ sulfamethoxazole (SMP) and $160 \mathrm{mg}$ trimethoprim (TMP) initially, which was decreased to 800/160 twice or three times a week in maintenance therapy. Severity of scleritis was evaluated clinically and graded on a 0 to $4+$ scale where 0 represented the absence of scleral inflammation and $4+$ the most severe form. ${ }^{4}$

Between January 2000 and December 2012, 20 patients with idiopathic anterior scleritis treated with CTX were identified. The characteristics of these patients are summarized in Table 1. Six patients were reported previously. ${ }^{5}$

Seventeen women and 3 men with a total of 32 affected eyes are described. Median age at CTX initiation was 61 years (range, 32-80). There were more cases of nodular (21 affected eyes) than diffuse scleritis (11 affected eyes). The duration of scleritis 


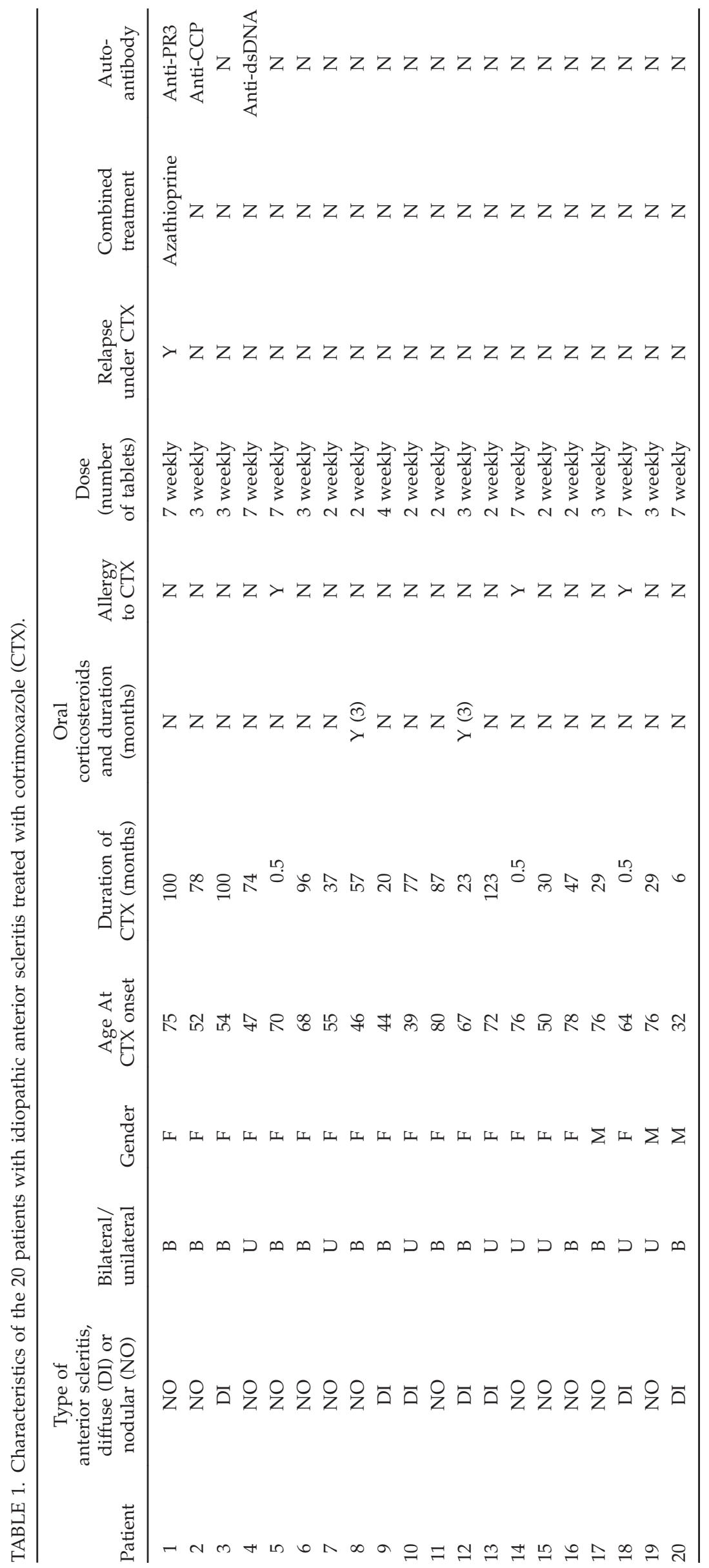



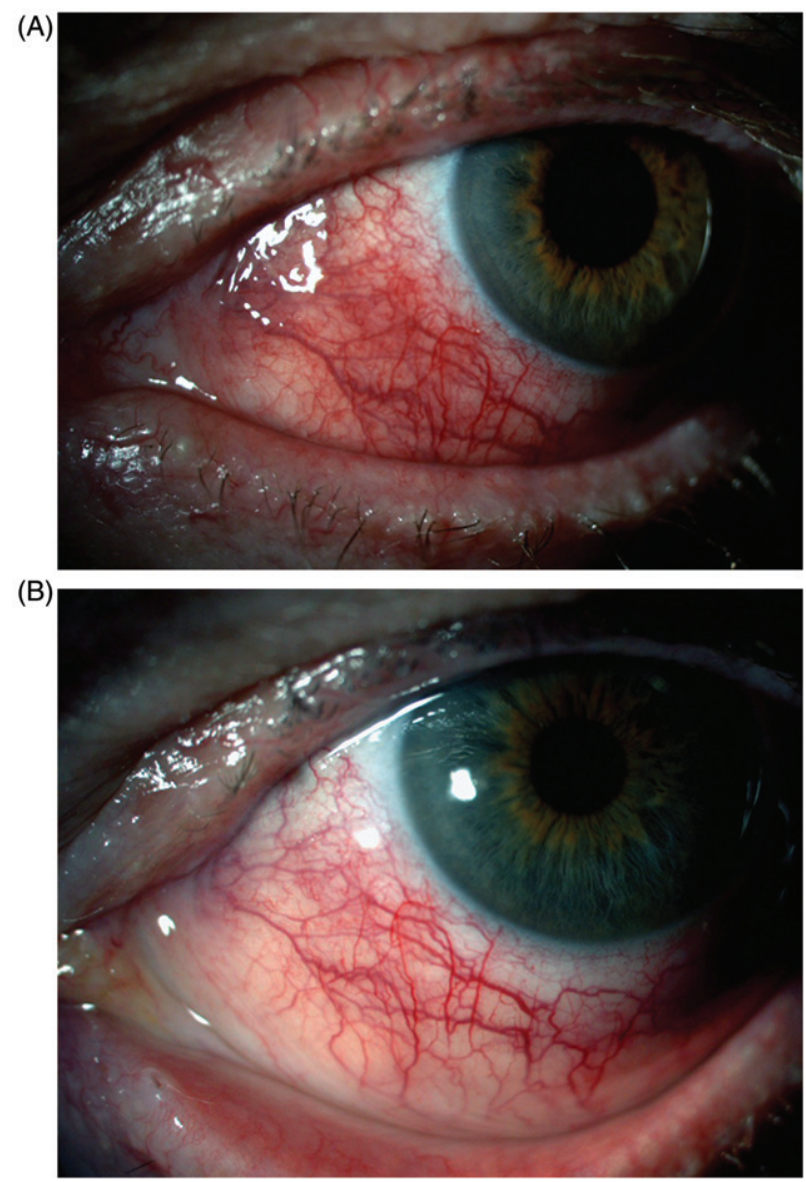

FIGURE 1. (A) Diffuse anterior idiopathic scleritis in the left eye of a 55-year-old patient before treatment. (B) Same eye after 1 month of treatment with systemic cotrimoxazole.

before CTX treatment was $2-4$ years. Before CTX treatment, all the patients had had at least four episodes of acute anterior scleritis within the previous 2 years and had also benefited from a NSAIDs treatment unless a contraindication or relapse was noted. Only the 2 patients with contraindications to NSAID received CTX as first-line treatment. Patients were given CTX 800/160 mg per day until scleritis remission and the lower maintenance dose was 2 tablets per week in the best responders ( 7 patients). All patients received $5 \mathrm{mg}$ folic acid, taken at the same time as CTX. The ocular and general status of each patient was controlled and recorded every 3 months with an ocular and general examination, blood samples including complete blood count, liver function tests, and assessment of renal function. The median follow-up since CTX initiation was 45.6 months (range, 20-123 months). None of the patients was lost to follow-up by January 2013. Two patients (patients 8 and 12) received 3 months of oral corticosteroid therapy in combination with CTX at the beginning of treatment. Inflammation was controlled in all 16 patients still under treatment with no local treatment or oral steroids. Pain due to scleritis improved after a mean period of 7 days and inflammation resolved in approximately 1 month for all patients (Figure 1). Eleven experienced at least one relapse when stopping the treatment on their own, but the treatment was effective again when reintroduced.

Treatment was discontinued in 4 out of 20 patients. In patient 1, CTX was stopped after 100 months of treatment because of a relapse, and azathioprine controlled the disease. In 3 patients, CTX had to be stopped because of acute cutaneous allergy occurring within 2 weeks. These episodes resolved within 1 week with the help of anti-histaminic drugs. No other serious side effect was reported during the follow-up, in particular no renal insufficiency, hepatic dysfunction, or anemia.

No systemic disease was discovered during the follow-up. Auto-antibodies were identified in 3 patients. Patient 1 had low titers of anti-proteinase 3 antibodies but no other signs of GPA. Patient 2 had low anti-CCP titers but no rheumatoid factor or any clinical evidence of rheumatoid arthritis. Patient 4 had low positive ELISA ds-DNA antibody titers without any sign of systemic lupus erythematosus.

To our knowledge, the only report of CTX efficacy in idiopathic anterior scleritis in the literature is from Soukiasian et al. $^{7}$ A patient with scleritis and a conjunctival nodule was reported; the nodule was biopsied and ANCA-positive GPA was diagnosed. As no other manifestation was found, the diagnosis of localized GPA was made and the patient was treated with CTX.

CTX is a drug involved in several pathways:

- Inhibition of folic acid synthesis. CTX competitively inhibits the dihydropteroate synthase enzyme and inhibits the incorporation of paraaminobenzoic acid into dihydropteroic acid, the immediate precursor of folic acid. TMP inhibits the dihydrofolate reductase enzyme and blocks folate/folinate conversion. ${ }^{8}$

- Immunosuppressive effect. The chemical structure of TMP contains the same pyrimidine ring as azathioprine. ${ }^{9}$

- In healthy volunteers, CTX inhibits the lymphoblastic transformation test in $84 \%$ of cases. ${ }^{10}$

- In Wegener disease (granulomatosis with polyangiitis), other more specific mechanisms are suggested: ${ }^{11}$

- Antibacterial activity has been reported on Staphylococcus aureus.

- CTX can interfere with free radicals production.

- CTX decreases the level of antinuclear cytoplasmic antibodies (ANCA) and the risk of relapse. CTX may be effective even in cases where cyclophosphamide and cortisone are ineffective, ${ }^{12}$ possibly due to the reduction of the immune response mediated by $\mathrm{T}$ lymphocytes with IL-2 elevation. 
- CTX decreases IL-2 levels by reducing the T lymphocyte response. ${ }^{13}$

Usually, CTX is also prescribed in ophthalmology for its antibacterial properties, such as in ocular toxoplasmosis or brucellosis. Scleral infections involve more particular bacteria, such as Nocardia asteroides, where CTX has been shown to be effective. ${ }^{3,14,15}$ Systemic NSAID therapy is usually recommended in the treatment of scleritis. ${ }^{1}$ If it is not effective, then corticosteroids or other immunosuppressive treatments, such as methotrexate, azathioprine, mycophenolate, or leflunomide, are prescribed. If these treatments are not effective, biotherapies could be tested, mainly anti-TNF-alpha. Cotrimoxazole could be a good choice if NSAID therapy is ineffective, before introducing more aggressive agents.

In summary, we report on the efficacy of cotrimoxazole in a case series of recurrent anterior idiopathic scleritis. At the moment, 16 out of 20 patients have shown a successful response, with no side effects. This treatment seems promising with a good balance between safety and efficacy. Further comparative studies with large series are needed to evaluate the yield of cotrimoxazole in the treatment of idiopathic anterior scleritis.

\section{DECLARATION OF INTEREST}

The authors report no conflicts of interest. The authors alone are responsible for the content and writing of the paper.

\section{REFERENCES}

1. Foster CS, Sainz de la Maza M. Scleritis. New York: Springer-Verlag; 1994.
2. Watson PG, Hayreh SS. Scleritis and episcleritis. $\mathrm{Br} J$ Ophthalmol. 1976;60:163-191.

3. Sainz de la Maza M, Molina N, Gonzalez-Gonzalez LA, et al. Clinical characteristics of a large cohort of patients with scleritis and episcleritis. Ophthalmology. 2012;119: $43-50$.

4. Sen HN, Sangave AA, Goldstein DA, et al. A standardized grading system for scleritis. Ophthalmology. 2011;118: 768-771.

5. Bielefeld P, Muller G, Vinit J, et al. Interest of cotrimoxazole in relapsing idiopathic anterior scleritis: about six cases. Rev Med Interne. 2006;27:524-526.

6. Falk RJ, Gross WL, Guillevin L, et al. Granulomatosis with polyangiitis (Wegener's): an alternative name for Wegener's granulomatosis. Arthritis Rheum. 2011;63:863-864.

7. Soukiasian SH, Jakobiec FA, Niles JL, et al. Trimethoprimsulfamethoxazole for scleritis associated with limited Wegener's granulomatosis: use of histopathology and anti-neutrophil cytoplasmic antibody (ANCA) test. Cornea. 1993;12:174-180.

8. Hitchings GH. A biochemical approach to chemotherapy. Drug Intell Clin Pharm. 1982;16:843-848.

9. Ghilchik MW, Morris AS, Reeves DS. Immunosuppressive powers of the antibacterial agent trimethoprim. Nature. 1970;227:393-394.

10. Gaylarde PM, Sarkany I. Suppression of thymidine uptake of human lymphocytes by co-trimoxazole. Br Med J. 1972;3: 144-146.

11. DeRemee RA, McDonald TJ, Weiland LH. Wegener's granulomatosis: observations on treatment with antimicrobial agents. Mayo Clin Proc. 1985;60:27-32.

12. Puolijoki H, Liippo $K$, Raitio $M$, et al. Wegener's granulomatosis-treatment under revision? Respiration. 1992;59:116-118.

13. Ballieux BE, van der Burg SH, Hagen EC, et al. Cellmediated autoimmunity in patients with Wegener's granulomatosis (Wg). Clin Exp Immunol. 1995;100:186-193.

14. Sridhar MS, Cohen EJ, Rapuano CJ, et al. Nocardia asteroides sclerokeratitis in a contact lens wearer. CLAO J. 2002;28: 66-68.

15. Maruo H, Shiraishi A, Hara Y, et al. Necrotizing nocardial scleritis successfully treated with surgical debridement and topical polyvinyl alcohol iodine and antibiotics. J Ocul Pharmacol Ther. 2011;27:415-418. 